\title{
The study of the phenomenon of self-employment and its role in the national economy: the case of Kazakhstan
}

\author{
Dinara Rakhmatullayeva ${ }^{1, *}$, Guliya Iliyashova $^{1}$, Altynai Maukenova ${ }^{2}$, and Yernazar Ishanov ${ }^{1}$ \\ ${ }^{1}$ Al-Farabi KazNU, Economics Department, 050040, Al-Farabi Av. 71, Kazakhstan \\ ${ }^{2}$ Asfendiyarov KazNMU, Department of IESHM, 050000, Tole Bi St. 94, Kazakhstan
}

\begin{abstract}
This article explores the urgent problem of the role of the selfemployed population in the development of the national economy. An empirical review of foreign literature allowed the authors to identify the causes and consequences of self-employment of the population. Statistical comparative analysis was used to study trends in the structure of the workforce, as well as the main macroeconomic indicators of the republic. Based on the results, the authors attempted to investigate the potential impact of the self-employed on the socio-economic development of Kazakhstan and assess existing measures to regulate self-employment in the country.
\end{abstract}

Keywords. Self-employment, Kazakhstan, socio-economic development, national economy.

\section{Introduction}

The innovative path of development of the national economy determines a rapid change in all spheres of society, not only economic, but also social. It is well known that the quality of development of the productive forces of society plays a decisive role in determining where and when the country will be on the path of its development.

In the modern rapidly changing world, where the influence of information and communication technologies on the development of the economy and society is growing and inevitably intensifying, the structure of the labor market is especially changing. This fact is recognized by many experts who believe that new technologies, robotics and automation complicate the requirements for labor resources and the quality of human capital. This means that in the place of old professions new ones come, the need for which is growing rapidly, the boundaries between formally and informally employed in terms of better providing themselves with income and material wealth, satisfaction with their work, life and confidence in the future are being erased.

Of course, the development of the national economy and the labor market are interrelated and interdependent processes, and have various causes and consequences of development and influence both on each other and on the development of society, in general, with a large gap between them.

\section{Data and Methods}

For the study, the authors used indicators characterizing the composition of the country's labor force, and also analyzed some macroeconomic indicators of the republic. The first group of indicators includes the total number of labor force, employees, selfemployed and unemployed. To analyze the socio-economic development of the country, GDP per capita, labor productivity, the number of registered SMEs, average monthly income per capita, the share of the population with incomes below the subsistence level

\footnotetext{
${ }^{*}$ Corresponding author: dintash76@gmail.com
} 
were used.

The authors confirm that all indicators are taken from the official statistical database of the Committee on Statistics of the Ministry of National Economy of the Republic of Kazakhstan (CS MNE RK) for a five-year period from 2013 to 2017 [1]. The authors chose this time period based on the fact that the official accounting of the self-employed in the employed population was introduced in 2013.

In this study the authors based on the Methodology for calculating the number of selfemployed, their average monthly income and the number of unemployed people [2]. This methodology was developed by the CS MNE of the Republic of Kazakhstan in accordance with the standards of the International Labor Organization (ILO), and it defines the criteria for classifying a person as a self-employed population, as well as two forms of selfemployment - productive and unproductive.

The following research methods also served as the methodological basis for the study: analysis and synthesis, statistical methods, logical method, comparative analysis, system analysis, generalization.

\section{Literature review}

The phenomenon of the self-employed population is "disturbing" the minds of researchers and specialists in the field of employment, government agencies that regulate processes in the labor market. The scientists are interested in self-employment as a form of precarious employment, or precariat, and its potential impact on the social and economic development of the country [3]. The government's interest in self-employment is determined, to a greater extent, by the fact that "... self-employed citizens must contribute to the achievement of the country's development goals ..." [4], and the government should be able to regulate new processes in the labor market that are not amenable to existing forms and tools of control.

The authors cited popular definitions of the "self-employed population" category, for example, in accordance with the ILO definition until 2019, self-employed are people engaged in their own economic activities, regardless of the type of contract, or whether they hire other people (or not) [ 5]. According to recent changes, the concept of "self-employed" has been replaced by "independent worker". Other definition related to the OECD (2017), according to it self-employment is defined as the employment of employers, self-employed workers, members of production cooperatives and unpaid family workers [6].

The phenomenon of self-employment began to be considered in the second half of the last century when studying the causes of entrepreneurship, for example, foreign researchers such as Herbert \& Link (1988), Barreto (1989), Stevenson et al (1990) investigated the reasons why people preferred self-employment to hired labor [7-9]. Whereas in foreign studies selfemployment is unambiguously associated with innovations and defines it as a type of entrepreneurship, in the post-Soviet space self-employment was perceived ambiguously. For example, Toksanbayeva (1998) noted that self-employment can be negative for an employee and become an alternative to unemployment [10]. Volgyn (1999) considered selfemployment as a form of economic activity when a person organizes the labor process, the results of which provide him with a decent existence [11]. By Volovskaya (2001), selfemployment is based on personal initiative, independence and responsibility [12].

In a study of the reasons for the development of entrepreneurial activity, Baumol (1990) determined that people are motivated by the reward structure in the economy [13]. In the Eisenhauer model (1995), the basis of a person's choice of doing business is the high expected utility [14]. Douglas and Shepherd (2000) also found that people prefer selfemployment when a combination of efficiency and independence provides greater utility than a better employment option [15]. Kim (2007) showed that the likelihood of selfemployment increases with age and education, and is higher for men and married women compared to other populations [16]. 
Some researchers drew attention to the lack of involvement of the self-employed in the formal economy. For example, Startienè et al (2013), using expert assessment and correlation analysis methods, evaluated the impact of a set of self-employment factors on the duration of self-employment in Lithuania [17]. An analysis of Kukk et al (2014) confirmed that in Estonia the share of declared business income is indeed a better indicator of underreporting than declared employment [18]. Cabral et al (2018) proved that in New Zealand, self-employed people underestimate on average about $20 \%$ of their income [19].

Domestic science has been concerned with the category of self-employment for the past twenty years. For example, Meldekhanova (1999) considered self-employment as a prerequisite for the development of entrepreneurship in Kazakhstan [20], Jumambaev (2011) identifies self-employment with the creation of their own individual enterprises without employees [21]. Mussurov et al (2015) conducted a study among self-employed men and women in Kazakhstan to identify the causes of informality. Dodonov (2016) raised the issue of formalization of the self-employed and defines them as representatives of small business [22].

Thus, a review of theoretical material showed that self-employment has an ambiguous effect on the economy - on the one hand, it stimulates the development of entrepreneurship in the country and can become a catalyst for many positive changes in the economy and other areas of social development. On the other hand, self-employed, working in the "shadow", can contribute to the growth of the informal sector of the economy.

\section{Results}

The authors investigated the trends in the indicators of the composition of the labor force and the structure of the self-employed population in Kazakhstan for the period 20132017. As noted earlier, the authors chose this time period based on the fact that the official registration of the self-employed as part of the employed population in the republic was introduced in 2013. It was then that the Kazakhstan's methodology was developed for calculating the number of self-employed and the level of their average monthly income in accordance with ILO standards. The analysis of the dynamics of statistical data on the composition of the labor force is shown in Fig. 1.

\begin{tabular}{|c|c|c|c|c|c|c|}
\hline & 10000,0 & & & & & \\
\hline & 9000,0 & 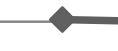 & $\hat{~}$ & 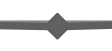 & - & 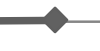 \\
\hline & 8000,0 & & & & & \\
\hline$\frac{0}{2}$ & 7000,0 & & & & & \\
\hline ¿ & 6000,0 & -5 & $-2=$ & $=$ & - & -1 \\
\hline $\bar{E}$ & 5000,0 & & & & & \\
\hline 绨 & 4000,0 & & & & & \\
\hline & 3000,0 & 4 & 1 & . & . & \\
\hline & 2000,0 & & & & & \\
\hline & 1000,0 & $x$ & * & ㄷ & $x$ & $x$ \\
\hline & 0,0 & 2013 & 2014 & 2015 & 2016 & 2017 \\
\hline & Labor force & 9041,3 & 8962,0 & 8887,6 & 8998,8 & 9027,4 \\
\hline & -Wage-earners & 5949,7 & 6109,7 & 6294,9 & 6342,8 & 6485,9 \\
\hline & - Self employed & 2621,0 & 2400,4 & 2138,4 & 2210,5 & 2099,2 \\
\hline & $\star$ Unemployed & 470,7 & 451,9 & 454,2 & 445,5 & 442,3 \\
\hline
\end{tabular}

Fig. 1. Dynamics of labor force indicators in Kazakhstan, 2013-2017 [1]

A substantial analysis of the diagram and data in Figure 1 showed that there is a slight decrease in the total labor force by $0.03 \%$ for the period under review. More specifically, 
the number of employees in the labor force increased by an average of $2.2 \%$, while the number of self-employed decreased by an average of $5.3 \%$. As for the unemployed population, its number decreased, on average, by $1.5 \%$. Thus, official statistics show positive trends in the change in the structure of the workforce over a five-year period. If we analyze separately the trends in the structure of the self-employed population, we get the following situation (Fig. 2).

\begin{tabular}{|c|c|c|c|c|c|}
\hline $\begin{array}{l}3000000 \\
2500000 \\
2000000 \\
1500000 \\
1000000 \\
500000\end{array}$ \\
\cline { 2 - 7 }
\end{tabular}

Fig. 2. The structure of the self-employed population for 2013-2017. [1]

The chart data in Figure 2, in turn, demonstrate an annual decline in unproductive selfemployed in the self-employed population, despite the fact that the total number of selfemployed slightly increased in 2016 by $3.4 \%$, then began to decline again in 2017. A positive fact is that during the period under review there is a positive trend in the indicator of productive self-employed in Kazakhstan. For a more detailed analysis, the authors calculated the average growth/decline rate of self-employed structure indicators in $\%$ of the previous year (Tab. 1).

Tab. 1. Average rate of growth/decline in the number of self-employed

\begin{tabular}{|c|c|c|c|c|c|c|}
\hline \multirow[t]{2}{*}{ No } & \multirow{2}{*}{ Categories of self-employed } & \multicolumn{5}{|c|}{$\begin{array}{l}\text { The average rate of growth/decline, in } \% \text { of } \\
\text { the previous year }\end{array}$} \\
\hline & & 2014 & 2015 & 2016 & 2017 & сред \\
\hline 1 & $\begin{array}{l}\text { Unproductive self-employed, } \\
\text { people }\end{array}$ & $-29,9$ & $-53,3$ & $-9,0$ & $-27,7$ & $-30,0$ \\
\hline 2 & Productive self-employed, people & 5,1 & 6,9 & 5,6 & $-1,5$ & 4,0 \\
\hline 3 & Total self-employed, people & $-8,4$ & $-10,9$ & 3,4 & $-5,0$ & $-5,2$ \\
\hline
\end{tabular}

An analysis of Tab. 1 confirmed that over the five years there has been a decrease in the total number of self-employed Kazakhstanis in the range of 5-11\%, however, the average rate of decline was $5.2 \%$, because in 2016 their growth was $3.4 \%$. In addition, as part of the self-employed population, the number of unproductive self-employed people is declining at a fairly high pace, and this is a positive moment for government agencies. The indicator showed the largest decrease in 2015 - by 53\%, and the smallest decrease of it was in 2016 - 
by $9 \%$. At the same time, it is alarming that in 2017 there was a decrease in productively self-employed people by $1.5 \%$, although the average value for the period smoothed this result, as a result, there is an increase in the number of productive self-employed by $4 \%$ for the entire period.

To study the role and influence of the self-employed population not only on the structure of the labor force in the country, but also on the economic development of Kazakhstan, in general, the authors attempted to conduct a comparative correlation analysis of labor market trends with macroeconomic indicator's trends in the national economy. For this, the authors analyzed the following indicators: GDP per capita, labor productivity, the number of registered SMEs, average monthly income per capita, average consumer spending per capita, the share of the population with incomes below the subsistence level. Tab. 2 shows their dynamics over the same period and their average growth / decline rates in $\%$ were also calculated.

Tab 2. Dynamics of indicators of the economy of the Republic of Kazakhstan for 2013-2017. [1]

\begin{tabular}{|l|c|c|c|c|c|c|}
\hline \multicolumn{1}{|c|}{ Indicators } & 2013 & 2014 & 2015 & 2016 & 2017 & $\begin{array}{c}\text { Average } \\
\text { rate, } \%\end{array}$ \\
\hline GDP per capita, thous.Tg & 2113,2 & 2294,8 & 2330,4 & 2639,7 & 2943,9 & 8,7 \\
\hline $\begin{array}{l}\text { Labor productivity, } \\
\text { thous.Tg }\end{array}$ & 3560,7 & 4007,4 & 4176,1 & 4226,4 & 4700,9 & 7,3 \\
\hline Number of registered SMEs & 1536,0 & 1655,4 & 1481,5 & 1498,2 & 1540,6 & 0,3 \\
\hline $\begin{array}{l}\text { Average monthly income } \\
\text { per capita, thous.Tg }\end{array}$ & 109,1 & 120,6 & 125,9 & 143,1 & 150,5 & 8,4 \\
\hline $\begin{array}{l}\text { Average consumer spending } \\
\text { per capita, thous.Tg }\end{array}$ & 386,8 & 411,1 & 426,8 & 465,8 & 514,7 & 7,4 \\
\hline $\begin{array}{l}\text { Share of the population with } \\
\text { incomes below the } \\
\text { subsistence level, \% }\end{array}$ & 2,9 & 2,8 & 2,7 & 2,6 & 2,6 & $-2,7$ \\
\hline
\end{tabular}

Analysis of the data in Tab. 2 showed that the dynamics of all indicators is positive for the study period, with the exception of the indicator of the share of the population with incomes below the subsistence level, but its negative result only proves the positivity of this process. At the same time, approximately the same growth rate is found in four of the six indicators - GDP, labor productivity, consumer spending and average monthly income - at the level of $7-8 \%$ over five years.

Comparing the values of the average rate of change in indicators of tables 1 and 2, the authors came to the following conclusions: there is an obvious positive correlation between trends in self-employment and trends in social and economic indicators of country (Tab. 3).

Tab. 3. Trends in changes in indicators of self-employment and the economy of Kazakhstan

\begin{tabular}{|l|l|c|c|}
\hline No & \multicolumn{1}{|c|}{ Indicator } & Value in \% & Change \\
\hline 1 & Number of self-employed & $-5,2$ & $\downarrow$ decline \\
\hline 2 & GDP per capita & 8,7 & $\uparrow$ growth \\
\hline 3 & Labor productivity & 7,3 & $\uparrow$ growth \\
\hline 4 & Number of registered SMEs & 0,3 & $\uparrow$ growth \\
\hline 5 & Average monthly income per capita & 8,4 & $\uparrow$ growth \\
\hline 6 & Average consumer spending per capita & 7,4 & $\uparrow$ growth \\
\hline 7 & $\begin{array}{l}\text { Share of the population with incomes } \\
\text { below the subsistence level }\end{array}$ & $-2,7$ & $\downarrow$ decline \\
\hline
\end{tabular}

An analysis of the data in Tab. 3 demonstrates that during the period under review, with a decrease in the self-employed population in the national economy, there was 
simultaneously an increase in GDP and labor productivity, an increase in SMEs, an increase in living standards due to an increase in average monthly income and consumer spending amid a decrease in the share of the poor.

As a result of a comparative analysis of trends in the structure of the employed population, the authors logically concluded that wage-earners in the employed population, unlike the self-employed, have a strong effect on changes in GDP, labor productivity and consumer spending. Regarding the impact of productive self-employed, most likely, they have a greater impact on the next indicators: the number of SMEs and the average monthly income of the population. In support of this statement, the authors believe that wage earners are more involved in the production of GDP, the growth of labor productivity and consumer spending, rather than self-employed. In turn, the productive self-employed are engaged in entrepreneurial activity than wage-earners. As a result they directly effect on the number of small and medium-sized enterprises in the country. Thus, they can significantly affect the level of consumer spending and potentially participate in the production of GDP, rather than unproductive self-employed. As for the latter, according to statistics, among them there are a large number of people whose incomes are very low, so their activity will more likely affect the indicator of the share of the population with incomes below the subsistence level.

As a result of the above, the authors suggest that the main priority for the population will always be the average monthly income and consumption level to create decent living standards; they may not care about the volume and dynamics of the country's GDP and the change in productivity. Consequently, the degree of influence of the self-employed population on the development of the economy can be significantly higher than that of wage earners, but it is important to clarify that we are talking about productive selfemployed. Therefore, government measures to promote productive employment and the development of entrepreneurship in the country are correct, however, it is equally important that they are real efficient.

Kazakhstan is a country that is constantly improving in the implementation of new ideas and models for the development of the national economy in order to increase the level and quality of life of the country's population. The ambitious goal of becoming one of the thirty leading countries of the world that to improve the quality of human capital based on the standards of OECD countries is quite achievable with a competent economic and social policy of the government of the republic. To this end, various state programs have been adopted and are being implemented to promote productive forms of employment in the republic, to develop entrepreneurship and to reduce unproductive employment and unemployment.

The Kazakh government, which for many years didn't officially recognize the status of a self-employed population, subsequently faced great difficulties in regulating the labor market. At the same time, studies of the reasons why the population of the republic choose selfemployment were actively carried out in the country and attempts were made to build a "portrait" of the self-employed, to study and adopt the positive experience of developed countries in the field of state regulation of this problem. As a result of this, the authorities realized the need to improve the existing institutional and legal framework of the labor market, having developed a methodology for calculating the self-employed population. This measure of the government allowed attributing of self-employment to the employed, and not to the unemployed, to identify the criteria by which the subject of the labor market is recognized as self-employed, the types and forms of self-employment, to keep its records and statistics.

Nowadays, an important step was the fact that for the first time in Kazakhstan it was developed and introduced not an administrative, but an economic mechanism for regulating the activities of the self-employed population. We are talking about the introduction of a single aggregate payment (SAP) for the self-employed from January 1, 2019. This is a special tax regime that will allow the self-employed to be included in the country's social and medical 
insurance system and will give them access to bank lending. According to the authors, the question of how will be effective this measure for both the state and the self-employed can be assessed after several reporting years. It is important to mention here that for the state a positive effect can be revealed only in the long term, but the government should implement an effective social policy, the influence of which should extend to all citizens of the republic.

As a result of the study, the authors revealed that the influence of the self-employed population on the development of Kazakhstan is potentially significant, and therefore it is important to remove productively self-employed from the shadow economy into the formal sector of the national economy and, thereby, contribute to their legalization and formalization. First of all, it will increase the level of social protection of the self-employed themselves.

\section{Conclusions}

The labor market is changing flexibly in response to global challenges in the development of human capital and Internet technologies; the popularity of "free" professions is growing every day, allowing people to realize themselves in the direction in which they are most comfortable working and earning income. At the same time, a large proportion of the population is forced to engage in informal activities, because they do not have highly competitive competencies and are not able to obtain them due to low incomes. And this situation is also due to the influence of changing market conditions and the structure of aggregate demand, general crisis trends in the development of national economies and labor markets, uneven development of production sectors and the distribution of labor resources by region and other factors.

Thus, it is fair to consider self-employment as a multifaceted and complex phenomenon, while highlighting the fact of its close relationship with entrepreneurship. If you recall $\mathrm{J}$. Schumpeter, he once wrote that a self-employed person is constantly connected with innovation and, as a factor in production, stimulates the innovative development of the economy. According to the authors, this means that the self-employed, no matter what type of activity he is engaged in, will voluntarily "integrate into the production chain" and participate in the production of products for society, and he will engage in business for the purpose of material and moral satisfaction of personal needs. Consequently, it is obvious and necessary to stimulate productive independent forms of entrepreneurial employment in the country, provide them with a preferential tax regime and create sufficient conditions for them to do business. Because in response to these measures they will create new jobs in the economy and stimulate private domestic investment, as a result, not only the number of start-up and innovation projects in the country will increase, but also the level of income and life of the entire population will increase.

\section{References}

1. Official internet resource of KSMNE RK (2020). URL: http://stat.gov.kz

2. Methodology for calculating the number of self-employed, their average monthly income and the number of unemployed, Astana, (2013)

3. V. Bobkov, N. Loktyukhina, V. Cvachev, Criteria, probability and degree of job instability taking into account the peculiarities of the Russian labor market, ER, 3, 81-86 (2017)

4. R. Mukuchyan, Development of tools and mechanisms for organizing and stimulating innovative self-employment of the population in the Russian economy, Diss. Of cand.science, 261 (2014)

5. ILO, Non-standard form of employment, report for discussion at the meeting of experts on non-standard forms of employment, MENSFE/2015 (2015)
6. OECD,
Database:
Self-employment
rate.
URL:

https://data.oecd.org/emp/selfemployment-rate.htm. (2017)

7. R. Herbert, A. Link, The Entrepreneur - Mainstream Views and Radical Critiques, Praeger, NY (1988) 
8. H. Barreto, Routledge, The Entrepreneur in Microeconomic Theory: Disappearance and Explanation. Routledge, London (1989)

9. H. Stevenson, J. Jarillo, A paradigm of entrepreneurship: entrepreneurial management, SM, 11, 17-27 (1990)

10. M. Toksanbayeva, Self-employment and its contradictions, ESMR, 3, 32-45 (1998)

11. N. Volgyn, Labor market and population incomes, M.: IPH «Filin», 280 (1999)

12. N. Volovskaya, Economics and sociology of labor, M., 87 (2001)

13. W. Baumol, Entrepreneurship: productive, unproductive, and destructive, JPE, 98, 893-921 (1990)

14.J. Eisenhauer, The entrepreneurial decision: economic theory and empirical evidence, ETP, 19(4), 67-79 (1995)

15.E. Douglas, D. Shepherd, Entrepreneurship as a utility-maximizing response, JBV, 15(3), 231-251 (2000)

16. Gi Seung Kim, The analysis of self-employment levels over the life-cycle, QREF, 47, Iss. 3, 397-410 (2007)

17. G. Startienè, R. Remeikienè, Evaluation of the impact of self-employment factors on self-employment duration in the country with transition economy: a Lithuanian case, TEDE, 19(1), 125-140 (2013)

18. M. Kukk, K. Staehr, Identification of Income Underreporting by the Self Employed: Employment Status or Reported Business Income? ETWP, 1, (2014)

19. Ana G. Cabral, N. Gemmell, Estimating self-employment income-gaps from register and survey data: evidence for New Zealand, WPS, 7625 (2018)

20. M. Meldekhanova, Employment and economic growth: methodology, strategy and regulatory mechanism, EIMSE RK, 295 (1999)

21. S. Jumambayev, Self Employment Issues in Kazakhstan, WBW, 26, (2011)

22. A. Mussurov, G.R. Arabsheibani, Informal self-employment in Kazakhstan, JLD, 4, 9 (2015)

23. V. Dodonov, Improving Employment Efficiency in Kazakhstan: Assessing the Potential of Structural Change D.P-L-E, 2, 109-121 (2016) 